\title{
Exposed Implant after Immediate Breast Reconstruction - Presentation and Analysis of a Clinical Management Protocol
}

\section{Exposição de prótese após reconstrução imediata da mama: apresentação e análise de protocolo clínico}

Rafael Amin Menezes Hassan ${ }^{10}$ Cícero de Andrade Urban ${ }^{1,2}$ Maíra Teixeira Dória2울 Cleverton Cesar Spautz ${ }^{20}$ Iris Rabinovich ${ }^{2,3(-)}$ Karina Furlan Anselmi ${ }^{20}$ Eduardo Schunemann Jr $r^{2,3}$

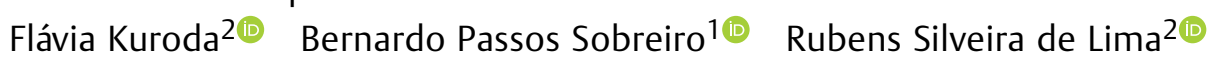

${ }^{1}$ Department of Post-graduation, Universidade Positivo, Curitiba, PR, Brazil

2 Breast Unit, Hospital Nossa Senhora das Graças, Curitiba, PR, Brazil

Address for correspondence Maíra Teixeira Dória, MsC, Rua Alcídes Munhoz 433, 80810-040, Curitiba, PR, Brazil

${ }^{3}$ Department of Obstetrics and Gynecology, Universidade Federal do (e-mail: maira_doria@yahoo.com.br).

Paraná, Curitiba, Paraná, PR, Brazil

Rev Bras Ginecol Obstet 2021;43(9):690-698.

\begin{abstract}
Objective Infection and exposure of the implant are some of the most common and concerning complications after implant-based breast reconstruction. Currently, there is no consensus on the management of these complications. The aim of the present study was to review our cases and to present a clinical protocol.

Methods We conducted a retrospective review of consecutive patients submitted to implant-based breast reconstruction between 2014 and 2016. All patients were managed according to a specific and structured protocol.

Results Implant exposure occurred in 33 out of 277 (11.9\%) implant-based reconstructions. Among these, two patients had history of radiotherapy and had their implant removed; Delayed reconstruction with a myocutaneous flap was performed in both cases. Signs of severe local infection were observed in 12 patients, and another 5 presented with extensive tissue necrosis, and they were all submitted to implant removal; of them, 8 underwent reconstruction with a tissue expander, and 2 , with a myocutaneous flap. The remaining 14 patients had no signs of severe infection, previous irradiation or extensive tissue necrosis, and were submitted to primary suture

\section{Keywords}

- breast neoplasm

- breast reconstruction

- exposed implant

- infection as an attempt to salvage the implant. Of these, 8 cases (57.1\%) managed to keep the original implant.

Conclusion Our clinical protocol is based on three key points: history of radiotherapy, severe infection, and extensive tissue necrosis. It is a practical and potentiallyreproducible method of managing one of the most common complications of implant-based breast reconstruction.
\end{abstract}

received

September 28, 2020

accepted

August 5, 2021
DOI https://doi.org/

$10.1055 / \mathrm{s}-0041-1735939$ ISSN 0100-7203.
(C) 2021. Federação Brasileira de Ginecologia e Obstetrícia. All rights reserved.

This is an open access article published by Thieme under the terms of the Creative Commons Attribution License, permitting unrestricted use, distribution, and reproduction so long as the original work is properly cited. (https://creativecommons.org/licenses/by/4.0/)

Thieme Revinter Publicações Ltda., Rua do Matoso 170, Rio de Janeiro, RJ, CEP 20270-135, Brazil 


\section{Resumo}

Palavras-chave
- neoplasia de mama
- reconstrução da
mama
- exposição de
implante
- infecção

Objectivo Infecção e exposição da prótese são algumas das complicações mais comuns e preocupantes após reconstrução da mama com implantes. Atualmente, ainda não há consenso quanto ao manejo destas complicações. O objetivo deste estudo foi o de revisar os casos da nossa instituição e apresentar um protocolo clínico.

Métodos Realizou-se uma revisão retrospectiva de todos os casos consecutivos submetidos a reconstrução mamária imediata com prótese entre 2014 e 2016. Todos os casos foram conduzidos de acordo com um protocolo específico e estruturado.

Resultados A exposição do implante ocorreu em 33 de 227 reconstruções (11,9\%). Dentre estas, duas pacientes tinham histórico de radioterapia, e foram submetidas a remoção da prótese e posterior reconstrução com retalho miocutâneo. Sinais de infecção local grave foram observados em 12 pacientes, e, em 5, necrose extensa de tecido, e todas foram submetidas a remoção dos implantes; destas, 8 foram reconstruídas com expansor, e 2, com retalho miocutâneo. As 14 pacientes remanecentes não haviam sido submetidas previamente à radioterapia, não tinham sinais de infecção, nem necrose extensa; portanto, foram submetidas a sutura primária em uma tentativa de salvar a prótese. Dessas, 8 pacientes $(57,1 \%)$ conseguiram manter os implantes originais.

Conclusão Nosso protocolo clínico é baseado em três pontos principais: histórico de radioterapia, infecção grave, e necrose extensa de tecido. Ele constitui um método prático e potencialmente reprodutível de manejo de uma das complicações mais comuns da reconstrução mamária com implantes.

\section{Introduction}

The rate of postmastectomy breast reconstruction (PMBR) has increased worldwide. ${ }^{1-5}$ In the United States, there was an increase of 35\% between 2000 and 2017, with more than 100 thousand procedures performed in 2017. ${ }^{6}$ In Brazil's public health system, the rate of PMBRs increased from $15 \%$ in 2008 to $29 \%$ in $2014 .{ }^{3}$ Breast reconstruction is associated with cosmetic and psychosocial benefits, and improvements in quality of life..$^{7-10}$ Among the different types of breast reconstruction, implant-based surgery is the most common option. ${ }^{1,2,11}$ Several studies ${ }^{12-15}$ have already demonstrated that this type of reconstruction is not associated with a negative impact on the oncologic results of breast cancer treatment, or with an increased risk of developing postoperative complications when compared with mastectomy alone.

Of all possible complications, implant infection and exposure remain major concerns, as they can lead to implant loss and bad cosmetic results. ${ }^{7,16-18}$ The rate of implant infection varies between $1 \%$ and $35.4 \%$, and exposure occurs in $0.25 \%$ to $8.3 \%$ of all implant-based breast reconstructions. ${ }^{19-23}$ Several factors are associated with implant infection and exposure: chemotherapy, radiotherapy, tumor size, obesity, older age, axillary dissection, smoking, and the comorbidities of the patient. ${ }^{16,19,24,25}$

Traditionally, implant infection is treated with antibiotic therapy, removal of the implant, and delayed reconstruction. ${ }^{23,26-30}$ More recently, cases of implant salvage have been reported. ${ }^{11,23,26,29-32}$ However, there is no consensus on the definition of implant salvage and on the clinical management of this situation. Device salvage might be defined as maintaining the implant itself, or the implant pocket, or even as salvage of the reconstructive result. ${ }^{11}$ The attempt of saving the implant may include only systemic antibiotics, or antibiotics associated with a surgical procedure (wound drainage, pocket lavage, capsulotomy, and implant exchange). ${ }^{11,26,29,31,32}$ To salvage exposed implants, authors report capsular flap coverage, ${ }^{33,34}$ device exchange with primary suture, ${ }^{26,31}$ or device exchange with muscular flap. ${ }^{26,31}$

In face of the lack of structured and clear information concerning the management of patients with implant exposure with or without infection after breast reconstruction, in the present manuscript, we review our cases and provide a clinical roadmap for the management of these patients.

\section{Methods}

We conducted a retrospective review of consecutive patients submitted to implant-based breast reconstruction between January 1st, 2014, and June 30st, 2016. Mastectomies were performed by one of seven surgeons of Breast Unit of Hospital Nossa Senhora das Graças, in the city of Curitiba, Southern Brazil. The same surgeon performed all breast reconstructions and managed the complications. Preoperative antibiotic prophylaxis with $2 \mathrm{~g}$ of Cefazolin was administrated in every case. Clindamycin was used for patients allergic to $\beta$-lactams. We used implants from two manufacturers: Allergan plc (Dublin, Ireland), and Mentor Worldwide LLC (Irvine, CA, United States). The study was approved by the local Ethics Committee (under protocol no. 178.554). 
The following demographic data were analyzed for each patient: age, presence of comorbidities, body mass index (BMI), smoking, previous breast surgeries, chemotherapy, radiotherapy, and axillary dissection. Regarding the surgical technique, the following data were evaluated: type of mastectomy (nipple-sparing or skin-sparing mastectomy), use of autologous tissue, timing of reconstruction (immediate or delayed), type of protheses (definitive or temporary), and breast weight. The type of reconstruction was defined individually for each patient by the surgical team, considering oncological staging, the patients' desire, biophysical characteristics, type of surgery, risk factors, and adjuvant treatment. Patients submitted to breast reconstruction with a different team of surgeons, those submitted to cosmetic surgeries, those with follow-up shorter than 3 months, and patients initially submitted to reconstruction with a myocutaneous flap were excluded.

The patients were treated according the same management protocol (-Fig. 1). Briefly, after identifying implant exposure, three factors are evaluated: previous irradiation, presence of infection, and presence of necrosis. For patients previously submitted to radiotherapy, implant removal and myocutaneous reconstruction is indicated. Primary suture or local flap advancement are indicated for those that have not received irradiation, have no signs of severe infection, and have minor necrosis. Patients presenting severe infection and/or extensive necrosis are submitted to implant removal and delayed recon- struction with a tissue expander after at least 3 months. If there is another failure in this second procedure, reconstruction with a myocutaneous flap is indicated.

Severe implant infection was defined as local inflammatory signs (erythema, edema, cellulitis, local warmth), with or without purulent discharge, associated with systemic inflammatory response (fever, leukocytosis, or hypotension). Necrosis of the flap was defined as absence of vitality of the overlying tissue, causing loss of function. Extensive necrosis is defined when there is no possibility of approaching the viable tissues surrounding the lesion.

\section{Statistical Analysis}

Descriptive data was presented as frequencies and percentages. The Pearson Chi-squared test was used to compare the rates of complications of each risk factor, and Fisher exact test was used when necessary. The Student $t$-test was used for the continuous variables, and the Mann-Whitney U test, for the ordinal variables. Values of $p<0.05$ were considered statistically significant. The software used was the Epi Info (Centers for Disease Control and Prevention, Atlanta, GA, United States), version 7.

\section{Results}

A total of 277 mastectomies with implant-based reconstruction were performed in 232 patients in the period analyzed.

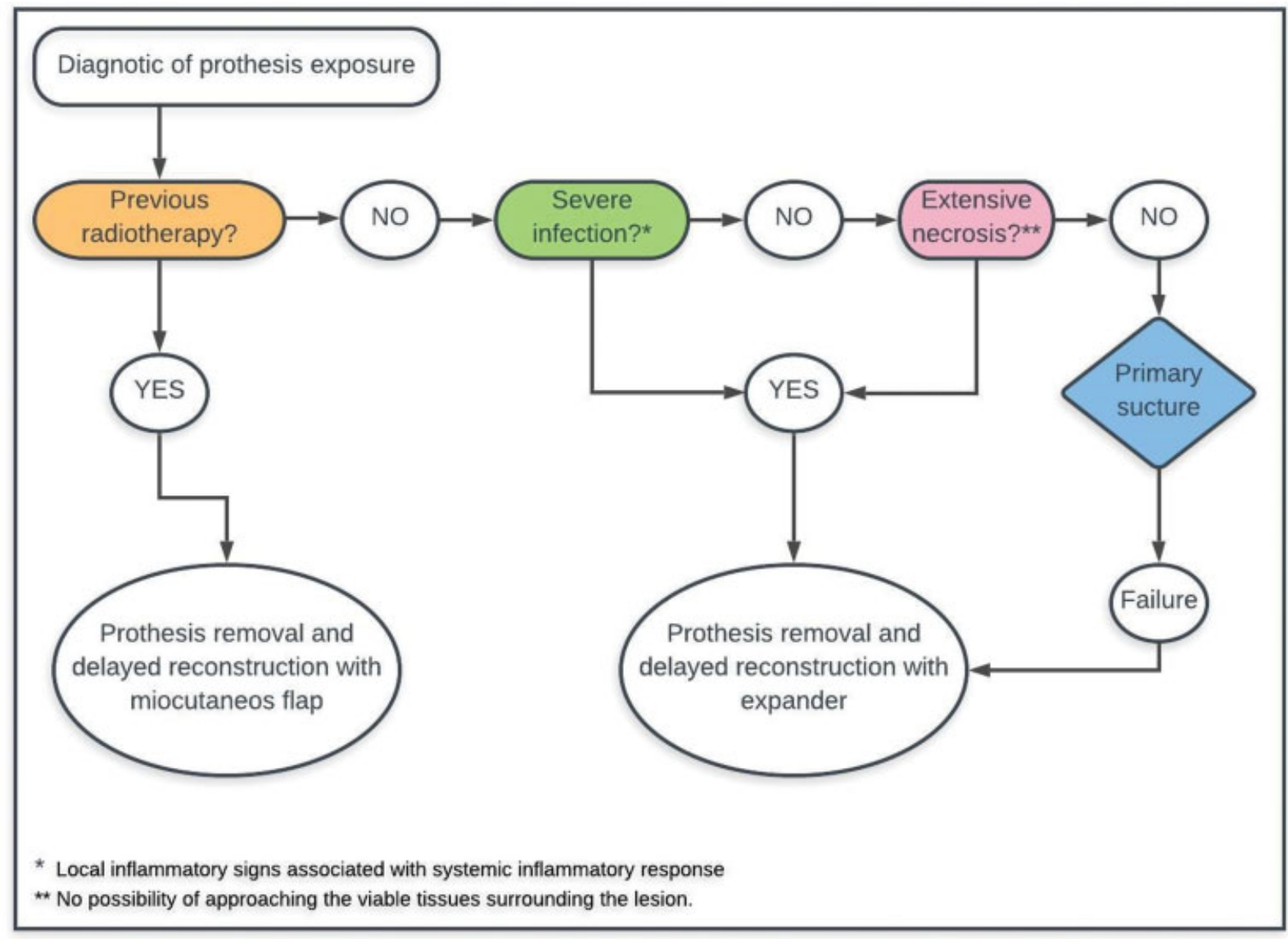

Fig. 1 Management protocol for exposed implants after immediate breast reconstruction. 
Of the 45 contralateral mastectomies performed, 32 (71.1\%) were prophylactic (11 with proven breast cancer relatedmutations, and the others with family history of breast cancer or presence of atypical lesions), and 13 (28.9\%) were oncologic (synchronic tumors). The mean follow-up was of 19.2 months.

- Table 1 shows the clinical and epidemiological characteristics of the study cohort. The mean age was of 50.2 years (range: 23 to 84 years), and $83 \%$ of the patients were younger than 65 years of age at the day of the surgery. Most patients

Table 1 Clinical and epidemiological characteristics of the study cohort

\begin{tabular}{|c|c|}
\hline Characteristic & Number of patients (\%) \\
\hline Age in years (standard deviation) & $50.2(10.56)$ \\
\hline \multicolumn{2}{|l|}{ Menopausal status } \\
\hline Premenopausal & $167(60.3 \%)$ \\
\hline Postmenopausal & $110(39.7 \%)$ \\
\hline \multicolumn{2}{|l|}{ Comorbidities } \\
\hline None & $220(79.4 \%)$ \\
\hline Cardiovascular disease & 45 (16.2\%) \\
\hline Diabetes & $16(5.8 \%)$ \\
\hline \multicolumn{2}{|l|}{ History of smoking } \\
\hline Yes & $34(12.3 \%)$ \\
\hline No & $243(87.7 \%)$ \\
\hline \multicolumn{2}{|l|}{ Body mass index } \\
\hline$\leq 25 \mathrm{~kg} / \mathrm{m}^{2}$ & $178(64.3 \%)$ \\
\hline $25-30 \mathrm{~kg} / \mathrm{m}^{2}$ & $66(23.8 \%)$ \\
\hline$\geq 30 \mathrm{~kg} / \mathrm{m}^{2}$ & 33 (11.9\%) \\
\hline \multicolumn{2}{|l|}{ Type of mastectomy } \\
\hline Skin-sparing mastectomy & 80 (28.9\%) \\
\hline Nipple-sparing mastectomy & 197 (71.1\%) \\
\hline \multicolumn{2}{|l|}{ Previous breast surgery } \\
\hline Yes & 55 (19.9\%) \\
\hline No & $222(80.1 \%)$ \\
\hline \multicolumn{2}{|l|}{ Radiotherapy } \\
\hline Prior to surgery & $12(4.3 \%)$ \\
\hline After surgery & $42(15.2 \%)$ \\
\hline No & $224(80.9 \%)$ \\
\hline \multicolumn{2}{|l|}{ Neoadjuvant chemotherapy } \\
\hline Yes & $76(27.4 \%)$ \\
\hline No & $201(72.6 \%)$ \\
\hline Mean weight of the breast (grams) & 408.06 \\
\hline \multicolumn{2}{|l|}{ Complications } \\
\hline No & $221(79.8 \%)$ \\
\hline Yes & $56(20.2 \%)$ \\
\hline Prothesis exposure & 33 (11.9\%) \\
\hline Small-tissue necrosis & $27(9.4 \%)$ \\
\hline Severe infection & $18(6.5 \%)$ \\
\hline Extensive necrosis & 7 (2.5\%) \\
\hline
\end{tabular}

did not have any comorbidities (79.4\%), and had BMIs of up to $25 \mathrm{~kg} / \mathrm{m}^{2}$ (64.3\%). Of all patients, $12.3 \%$ had history of smoking, and $27.4 \%$ received neoadjuvant chemotherapy. In total, 56 patients had 1 or more complications (20.2\%); of these, 36 needed hospitalization. The most common complication was implant exposure $(n=33 ; 11.9 \%)$, followed by small tissue necrosis $(n=27 ; 9.4 \%)$, severe infection $(n=18 ; 6.5 \%)$ and extensive necrosis $(n=7 ; 2.5 \%)$. The mean time between surgery and prosthesis exposure was of 7 weeks.

- Table 2 shows the comparison between patients with and without implant exposure. No associations were found regarding age, menopausal status, comorbidities, history of smoking, previous breast surgery, radiotherapy, type of surgery, type of prothesis, mean weight of the breast, and manufacturer of the prothesis. A higher proportion of BMIs between $25 \mathrm{~kg} / \mathrm{m}^{2}$ and $30 \mathrm{~kg} / \mathrm{m}^{2}$ was found among patients with exposure than among those without it $(30.3 \%(n=10$ out of 33 ) versus $22.9 \%$ ( $n=56$ out of 244 ) respectively), as well as a higher proportion of BMIs above $30 \mathrm{~kg} / \mathrm{m}^{2}(21.2 \%$ versus $10.7 \%$ respectively), but these findings were not statistically significant (odds ratio $[\mathrm{OR}]=1.68$; 95\% confidence interval $[95 \% \mathrm{CI}]: 0.72-3.90 ; p=0.17$; and $\mathrm{OR}=2.35$; 95\%CI: $0.90-6.18 ; p=0.06$ respectively). Among patients with implant exposure there was also a higher proportion of axillary dissection ( $27.3 \%$ ( $n=9$ out of 33 ) versus $18.9 \%$ ( $n$ $=46$ out of 244) among patients without exposure), although this difference was not statistically significant.

-Figure 2 illustrates the protocol for the management of all patients with implant exposure. The first question is if the patient had been previously submitted to radiotherapy. Of the 33 cases of exposed prosthesis, 2 (6.1\%) patients had history of radiotherapy and had their devices removed (-Fig. 3); delayed reconstruction with a myocutaneous flap was performed in both cases. The remaining 31 patients had not received radiotherapy, and were evaluated for signs of severe infection. The answer was affirmative in 12 cases, and they were submitted to implant removal. At the end of the follow-up, 4 of these patients had undergone reconstruction with a tissue expander, and 1 (8.3\%), with a myocutaneous flap. The remaining 7 patients (58.3\%) either chose not to proceed with the delayed reconstruction $(n=6)$, or did not have success with the second attempt $(n=1)$.

In total, 19 patients had no signs of severe infection or previous irradiation; of these, 5 (26.3\%) presented with extensive tissue necrosis (-Fig. 4). All of them were initially submitted to removal of the device. After the removal, 4 (66.7\%) patients underwent reconstruction with a tissue expander, and 1 (16.7\%), with a myocutaneous flap. One of these patients died due to the oncologic disease. The remaining $14(42.4 \%)$ patients had no signs of severe infection, previous irradiation, or extensive tissue necrosis, and were submitted to primary suture as an attempt to salvage the implant (-Fig. 4). Of these, the original implant was kept in 8 cases $(57.1 \%)$. Of the remaining 6 patients, 3 (50\%) changed the implant for a tissue expander; 2 (33.3\%) choose not to reconstruct the breast; and 1 (16.7\%) was submitted to reconstructiona with myocutenoues flap due to the bad quality of the skin. 
694 Exposed Implant after Immediate Breast Reconstruction Hassan et al.

Table 2 Univariate analysis between the two groups

\begin{tabular}{|c|c|c|c|c|}
\hline Characteristic & $\begin{array}{l}\text { Prothesis exposure } \\
(n=33)(\%)\end{array}$ & $\begin{array}{l}\text { No exposure } \\
(n=244)(\%)\end{array}$ & $\begin{array}{l}\text { Odds ratio } \\
\text { (95\% confidence interval) }\end{array}$ & Fisher exact \\
\hline \multicolumn{5}{|l|}{ Menopausal status } \\
\hline Premenopausal & $20(12.0 \%)$ & $147(88 \%)$ & $1.01(0.48-2.12)$ & NS $^{*}$ \\
\hline Postmenopausal & $13(11.8 \%)$ & $97(88.2 \%)$ & & \\
\hline \multicolumn{5}{|l|}{ Comorbidities** } \\
\hline None & $24(11.0 \%)$ & $196(89.0 \%)$ & & \\
\hline Diabetes & $2(12.5 \%)$ & $14(87.5 \%)$ & $1.16(0.25-5.45)$ & NS \\
\hline Cardiovascular disease & $8(18.0 \%)$ & 37 (82.0\%) & $1.76(0.74-4.23)$ & NS \\
\hline \multicolumn{5}{|l|}{ History of smoking } \\
\hline Yes & $5(14.7 \%)$ & $29(85.3 \%)$ & $1.32(0.47-3.70)$ & NS \\
\hline No & $28(11.5 \%)$ & 215 (88.5\%) & & \\
\hline \multicolumn{5}{|l|}{ Body mass index } \\
\hline$\leq 25 \mathrm{~kg} / \mathrm{m}^{2}$ & $16(9.0 \%)$ & 162 (91.0\%) & & \\
\hline $25-30 \mathrm{~kg} / \mathrm{m}^{2}$ & $10(15.1 \%)$ & 56 (84.9\%) & $1.80(0.77-4.21)$ & NS \\
\hline$\geq 30 \mathrm{~kg} / \mathrm{m}^{2}$ & $7(21.2 \%)$ & $26(78.8 \%)$ & $2.72(1.02-7.26)$ & NS \\
\hline \multicolumn{5}{|l|}{ Previous breast surgery } \\
\hline No & $29(13.1 \%)$ & 193 (86.9\%) & $0.52(0.17-1.55)$ & NS \\
\hline Yes & $4(7.3 \%)$ & $51(92.7 \%)$ & & \\
\hline \multicolumn{5}{|l|}{ Radiotherapy } \\
\hline No & $28(12.6 \%)$ & 195 (87.4\%) & & \\
\hline Prior to surgery & $1(8.3 \%)$ & 11 (91.7\%) & $0.63(0.07-5.09)$ & NS \\
\hline After surgery & $4(9.5 \%)$ & $38(90.5 \%)$ & $0.73(0.24-2.21)$ & NS \\
\hline \multicolumn{5}{|l|}{ Neoadjuvant chemotherapy } \\
\hline Yes & $10(13.1 \%)$ & 66 (86.9\%) & $1.17(0.53-2.59)$ & NS \\
\hline No & $23(11.4 \%)$ & $178(88.6 \%)$ & & \\
\hline Mean weight of the breast (grams) & 453.7 & 397.4 & $p=0.197^{* * *}$ & \\
\hline \multicolumn{5}{|l|}{ Type of mastectomy } \\
\hline Skin-sparing mastectomy & $11(13.8 \%)$ & $69(86.2 \%)$ & $1.26(0.58-2.75)$ & NS \\
\hline Nipple-sparing mastectomy & $22(11.1 \%)$ & 175 (88.9\%) & & \\
\hline \multicolumn{5}{|l|}{ Type of prothesis } \\
\hline Silicone & $20(13.4 \%)$ & $129(86.6 \%)$ & & \\
\hline Temporary expander & $2(11.8 \%)$ & $15(88.2 \%)$ & $1.16(0.24-5.47)$ & NS \\
\hline Definitive expander & $11(10.1 \%)$ & $98(89.9 \%)$ & $1.38(0.63-3.01)$ & NS \\
\hline \multicolumn{5}{|l|}{ Prothesis Manufacturer } \\
\hline Allergan plc & 19 (12.3\%) & $135(87.7 \%)$ & $1.05(0.50-2.20)$ & NS \\
\hline Mentor Worldwide LLC & $14(11.8 \%)$ & 105 (88.2\%) & & \\
\hline \multicolumn{5}{|l|}{ Axillary dissection } \\
\hline Yes & $9(16.4 \%)$ & $46(83.6 \%)$ & $1.68(0.73-3.88)$ & NS \\
\hline No & $23(10.4 \%)$ & $198(89.6 \%)$ & & \\
\hline
\end{tabular}

Abbreviation: NS, not significant.

Notes: ${ }^{*}$ The Fisher exact test was considered not significant when $p>0.05 .{ }^{* *}$ The percentage is over $100 \%$ because some patients had 2 or more comorbidities. ${ }^{* * *}$ The Student $t$-test was used for the comparative analysis of the means.

At the end of the follow-up, reconstruction was successful in $24(72.7 \%)$ out of 33 patients with prosthesis exposure. Considering all 277 patients, our success rate was of $96.7 \%$ $(n=268)$.

\section{Discussion}

Immediate breast reconstruction after mastectomy has become a widely-accepted surgical option, and it can yield good cosmetic 


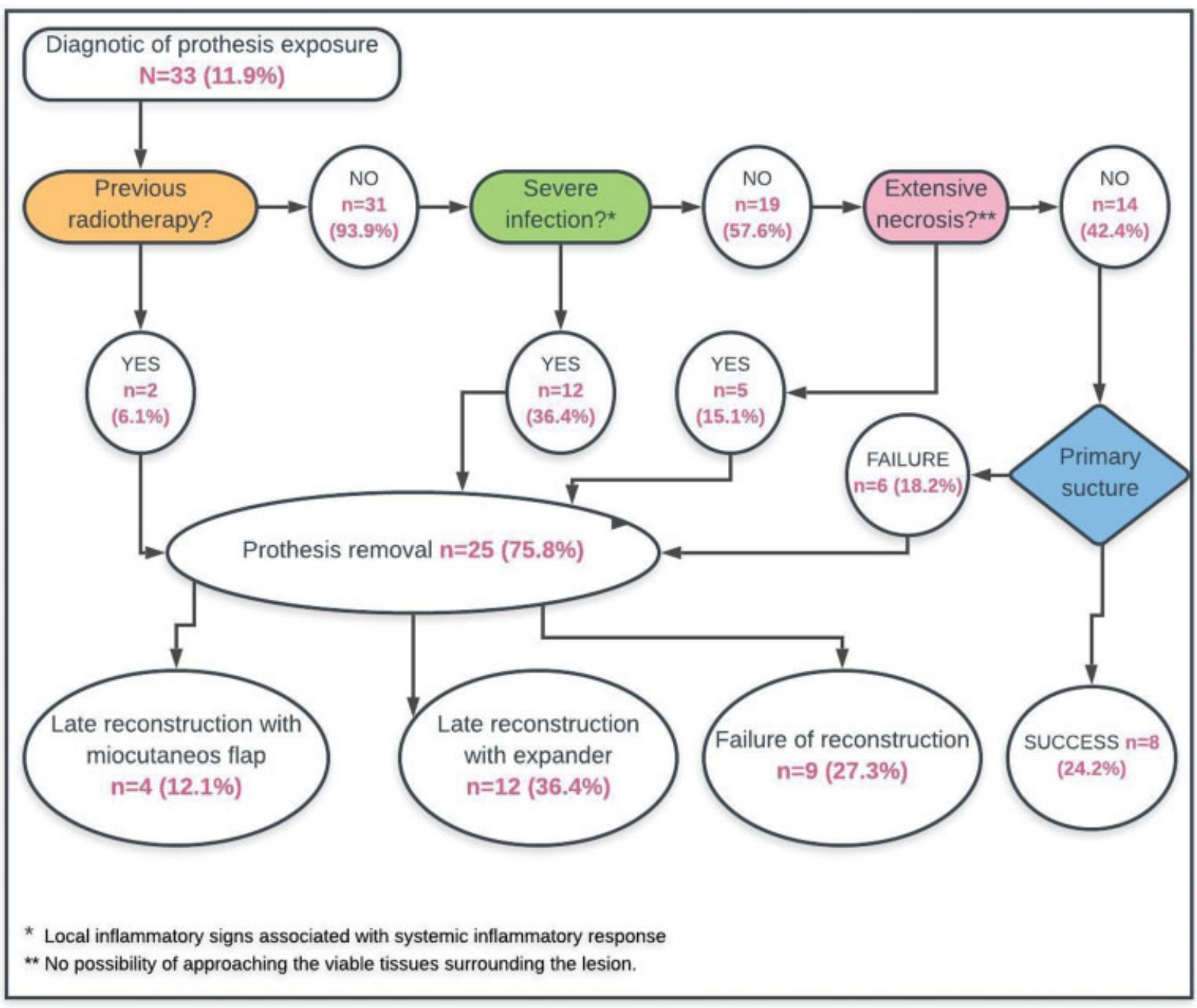

Fig. 2 Clinical management of the study cohort according to the protocol.

results, improving the quality of life of the patients. ${ }^{9}$ Surgical complications, such as implant exposure and/or infection, may result in the removal of the device, additional surgical procedures, bad cosmetic results, and psychological suffering for the patients. ${ }^{7,16-18,29}$ Therefore, precise management of these complications is imperative. In this manuscript, we presented a clinical protocol for exposed implants with and without associated infection. We also reviewed all cases of immediate implantbased reconstruction to evaluate the application of this protocol.
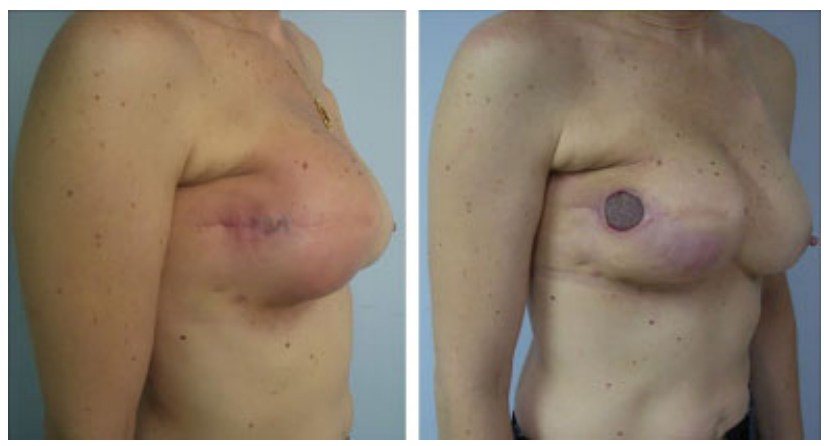

Fig. 3 Temporal evolution of extrusion in an irradiated patient.

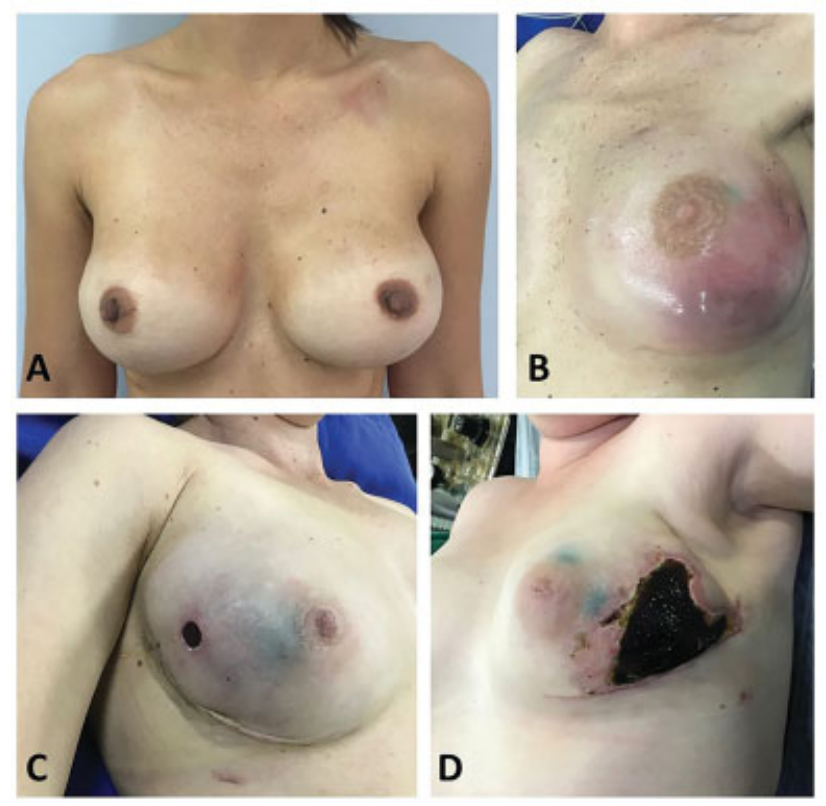

Fig. 4 Postoperative photographs after immediate reconstruction. (A) Good result after immediate reconstruction. (B) Local severe infection. (C) Minor exposure of the prothesis. (D) Extensive necrosis. 
Our complication rate of $20.2 \%$ is similar to that reported in the literature. ${ }^{16,18,25,35}$ of all complications, prosthesis exposure was the most common, and was present in $11.9 \%$ of our patients (33 out of 277 implant-based reconstructions). This percentage is slightly higher than that described by other authors, which ranges from $0.25 \%$ to $8.3 \% .^{19,20,23}$ Our high percentage of immediate reconstructions with definitive implants may be an explanation for this discrepancy. We have not found any statistically significant factors associated with prothesis exposure; this might be due to the small number of cases, as other authors have already demonstrated that smoking, radiotherapy, tumor size, obesity, older age, axillary dissection, chemotherapy, and patient comorbidities are associated with complications of reconstructions. ${ }^{16,19,24,25}$ Our rate of implant loss of 9.0\% (25 of 277 implant-based reconstructions) is comparable to those published in the literature, which vary from $0.9 \%$ to $13 \%{ }^{16-18}$

Our clinical protocol to manage the complications of implant-based reconstruction is based on clinical parameters and on the experience of a single surgeon. The first parameter is the history of radiotherapy. If the patient has been irradiated before, the exposed prosthesis must be removed. Bennett et al. ${ }^{31}$ evaluated 68 patients (with a total of 71 implant-based breast reconstructions) who developed infection or skin necrosis/exposure over a 20-year period. The patients were treated in one of three ways: explantation with or without delayed reconstruction; explantation with or without immediate autologous reconstruction; or implant salvage. Of the 20 patients submitted to the attempt to salvage the implant, $65 \%$ underwent radiotherapy prior to their complication. The implant was successfully kept in 4 (30.8\%) out of 13 patients with a history of radiotherapy, and in 5 (71.4\%) out of 7 with no history of radiotherapy. The authors ${ }^{31}$ concluded that patients previously submitted to radiotherapy have a higher rate of success when the size of the implant is reduced, or when new tissue, such as a flap, is introduced.

The second parameter to be analyzed is if the patient with the prosthesis exposed presents signs of severe infection. In that case, the implant is removed, and the patient receives systemic antibiotics. A delayed reconstruction is proposed after at least three months. Most authors who investigated the possibility of salvaging infected implants excluded patients with severe infection. ${ }^{11,31,32}$ Spear and Seruya ${ }^{26}$ reported their 15-year experience with the management of infected or exposed breast protheses after reconstructive or cosmestic surgery. A total of 69 patients with 87 events of breast device infection/exposure were included in the analysis. Out of 26 cases of severe infection without prosthesis exposure, the implant was successfully salvaged in 8 (30.8\%). On the other hand, none of the patients with severe infection and prosthesis exposure $(n=7)$ had their device salvaged. Therefore, the literature supports the decision contained in our protocol to remove the implant of the patients with severe infection and prosthesis exposure.

The last parameter is if there is extensive tissue necrosis. In this situation, there is no possibility of approximating the viable tissues surrounding the lesion, and the implant needs to be removed. If there is no sign of severe infection, no history of radiotherapy, and no extensive tissue necrosis, a primary suture is indicated. This approach was successful in 8 out of 14 patients (57.1\%) in the present study. Two studies $^{33,34}$ reported the use of a capsular flap to cover exposed implants after breast reconstruction. Brandstetter et al. ${ }^{33}$ reported the case of a patient presenting with a small exposure of breast implant after a skin-sparing mastectomy. The patient was submitted to capsulotomy, removal of the implant, lavage of the pocket, and insertion of a new implant, which was covered with a capsular flap. ${ }^{33}$ Varga et al. ${ }^{34}$ reported 19 cases of patients submitted to capsuloplasty after implant exposure; they did not specified the extent of the exposure and, in most of cases, new implants were used. Our data demonstrates that performing a primary suture can prevent the patients from undergoing an invasive surgical procedure, and it is successful in most cases.

There are limitations to the present study. First, the small number of patients with implant exposure was insufficient to demonstrate which risk factors are associated with this complication. However, it is important to emphasize that this was not the aim of the present study, as other authors have already investigated this subject. Second, the protocol presented needs to be validated by other groups of surgeons, as well as the patients' acceptance of its proposals.

\section{Conclusion}

Our clinical protocol combines the evidence from the literature, clinical and individualized data of the patient, and the experience of a surgeon specialized in breast reconstruction. This protocol, based on three key points (history of radiotherapy, severe infection, and extensive tissue necrosis), is a practical and potentially-reproducible method of managing one of the most common complications of implant-based breast reconstruction.

\section{Contributions}

All authors participated in the concept and design of the study; analysis and interpretation of data; and draft or revision of the manuscript. All authors have approved the manuscript as submitted, and are responsible for the reported research.

\section{Conflict of Interests}

The authors have no conflict of interests to declare.

\section{References}

1 Albornoz CR, Bach PB, Mehrara BJ, Disa JJ, Pusic AL, McCarthy CM, et al. A paradigm shift in U.S. Breast reconstruction: increasing implant rates. Plast Reconstr Surg. 2013;131(01):15-23. Doi: 10.1097/PRS.0b013e3182729cde

2 Alderman A, Gutowski K, Ahuja A, Gray DPostmastectomy ExpanderImplant Breast Reconstruction Guideline Work Group. ASPS clinical practice guideline summary on breast reconstruction with expanders and implants. Plast Reconstr Surg. 2014;134 (04):648e-655e. Doi: 10.1097/PRS.0000000000000541

3 Freitas-Júnior R, Gagliato DM, Moura Filho JW, Gouveia PA, Rahal RM, Paulinelli RR, et al. Trends in breast cancer surgery at Brazil's 
public health system. J Surg Oncol. 2017;115(05):544-549. Doi: $10.1002 /$ jso.24572

4 Karunanayake M, Bortoluzzi P, Chollet A, Lin JC. Factors influencing the rate of post-mastectomy breast reconstruction in a Canadian Teaching Hospital. Plast Surg (Oakv). 2017;25(04): 242-248. Doi: 10.1177/2292550317728034

$5 \mathrm{Ng}$ YY, Tan VK, Goh TL, Yong WS, Wong CY, Ho GH, et al. Trends in post-mastectomy reconstruction in an Asian population: a 12year institutional review. Breast J. 2017;23(01):59-66. Doi: 10.1111/tbj.12682

6 American Society of Plastic Surgeons. 2017 reconstructive plastic surgery statistics [Internet]. 2017 [cited 2018 Jul 28]. Available from: https://www.plasticsurgery.org/documents/News/Statistics/ 2017/reconstructive-procedure-trends-2017.pdf

7 Alderman AK, Wilkins EG, Lowery JC, Kim M, Davis JA. Determinants of patient satisfaction in postmastectomy breast reconstruction. Plast Reconstr Surg. 2000;106(04):769-776. Doi: 10.1097/00006534-200009040-0000

8 McCarthy CM, Klassen AF, Cano SJ, Scott A, Vanlaeken N, Lennox $\mathrm{PA}$, et al. Patient satisfaction with postmastectomy breast reconstruction: a comparison of saline and silicone implants. Cancer. 2010;116(24):5584-5591. Doi: 10.1002/cncr.25552

9 Kuroda F, Urban C, Zucca-Matthes G, de Oliveira VM, Arana GH, Iera $\mathrm{M}$, et al. Evaluation of aesthetic and quality-of-life results after immediate breast reconstruction with definitive form-stable anatomical implants. Plast Reconstr Surg. 2016;137(02): 278e-286e. Doi: 10.1097/01.prs.0000475746.17968.f4

10 Susarla SM, Ganske I, Helliwell L, Morris D, Eriksson E, Chun YS. Comparison of clinical outcomes and patient satisfaction in immediate single-stage versus two-stage implant-based breast reconstruction. Plast Reconstr Surg. 2015;135(01):1e-8e. Doi: 10.1097/PRS.0000000000000803

11 Franchelli S, Pesce M, Baldelli I, Marchese A, Santi P, De Maria A. Analysis of clinical management of infected breast implants and of factors associated to successful breast pocket salvage in infections occurring after breast reconstruction. Int J Infect Dis. 2018; 71:67-72. Doi: 10.1016/j.ijid.2018.03.019

12 Baker JL, Mailey B, Tokin CA, Blair SL, Wallace AM. Postmastectomy reconstruction is associated with improved survival in patients with invasive breast cancer: a single-institution study. Am Surg. 2013;79(10):977-981

13 Petit JY, Gentilini O, Rotmensz N, Rey P, Rietjens M, Garusi C, et al. Oncological results of immediate breast reconstruction: long term follow-up of a large series at a single institution. Breast Cancer Res Treat. 2008;112(03):545-549. Doi: 10.1007/s10549008-9891-x

14 Masoomi H, Paydar KZ, Evans GR, Tan E, Lane KT, Wirth GA. Does immediate tissue expander placement increase immediate postoperative complications in patients with breast cancer? Am Surg. 2015;81(02):143-149

15 Fischer JP, Wes AM, Tuggle CT, Nelson JA, Tchou JC, Serletti JM, et al. Mastectomy with or without immediate implant reconstruction has similar 30-day perioperative outcomes. J Plast Reconstr Aesthet Surg. 2014;67(11):1515-1522. Doi: 10.1016/j. bjps.2014.07.021

16 Petersen A, Eftekhari AL, Damsgaard TE. Immediate breast reconstruction: a retrospective study with emphasis on complications and risk factors. J Plast Surg Hand Surg. 2012;46(05):344-348. Doi: 10.3109/2000656X.2012.700025

17 Fischer JP, Nelson JA, Serletti JM, Wu LC. Peri-operative risk factors associated with early tissue expander (TE) loss following immediate breast reconstruction (IBR): a review of 9305 patients from the 2005-2010 ACS-NSQIP datasets. J Plast Reconstr Aesthet Surg. 2013;66(11):1504-1512. Doi: 10.1016/j.bjps.2013.06.030

18 Radovanovic Z, Radovanovic D, Golubovic A, Ivkovic-Kapicl T, Bokorov B, Mandic A. Early complications after nipple-sparing mastectomy and immediate breast reconstruction with silicone prosthesis: results of 214 procedures. Scand J Surg. 2010;99(03): 115-118. Doi: 10.1177/145749691009900302

19 Alderman AK, Wilkins EG, Kim HM, Lowery JC. Complications in postmastectomy breast reconstruction: two-year results of the Michigan Breast Reconstruction Outcome Study. Plast Reconstr Surg. 2002;109(07):2265-2274. Doi: 10.1097/00006534200206000-00015

20 Cordeiro PG, McCarthy CM. A single surgeon's 12-year experience with tissue expander/implant breast reconstruction: part II. An analysis of long-term complications, aesthetic outcomes, and patient satisfaction. Plast Reconstr Surg. 2006;118(04): 832-839. Doi: 10.1097/01.prs.0000232397.14818.0

21 Nahabedian MY, Tsangaris T, Momen B, Manson PN. Infectious complications following breast reconstruction with expanders and implants. Plast Reconstr Surg. 2003;112(02):467-476. Doi: 10.1097/01.PRS.0000070727.02992.54

22 Franchelli S, Pesce M, Savaia S, Marchese A, Barbieri R, Baldelli I, et al. Clinical and microbiological characterization of late breast implant infections after reconstructive breast cancer surgery. Surg Infect (Larchmt). 2015;16(05):636-644. Doi: 10.1089/ sur.2014.146

23 Spear SL, Howard MA, Boehmler JH, Ducic I, Low M, Abbruzzesse MR. The infected or exposed breast implant: management and treatment strategies. Plast Reconstr Surg. 2004;113(06):1634-1644. Doi: 10.1097/01.prs.0000117194.21748.02

24 Hughes K, Brown C, Perez V, Ting JWC, Rozen WM, Whitaker IS, et al. The effect of radiotherapy on implant-based breast reconstruction in the setting of skin-sparing mastectomy: clinical series and review of complications. Anticancer Res. 2012;32 (02):553-557https://ar.iiarjournals.org/content/32/2/553.long cited2018Jul7 [Internet]

25 Cowen D, Gross E, Rouannet P, Teissier E, Ellis S, Resbeut M, et al. Immediate post-mastectomy breast reconstruction followed by radiotherapy: risk factors for complications. Breast Cancer Res Treat. 2010;121(03):627-634. Doi: 10.1007/s10549-010-0791-5

26 Spear SL, Seruya M. Management of the infected or exposed breast prosthesis: a single surgeon's 15-year experience with 69 patients. Plast Reconstr Surg. 2010;125(04):1074-1084. Doi: 10.1097/PRS.0b013e3181d17fff

27 Forman DL, Chiu J, Restifo RJ, Ward BA, Haffty B, Ariyan S. Breast reconstruction in previously irradiated patients using tissue expanders and implants: a potentially unfavorable result. Ann Plast Surg. 1998;40(04):360-363, discussion 363-364. Doi: 10.1097/00000637-199804000-00007

28 Behranwala KA, Dua RS, Ross GM, Ward A, A'hern R, Gui GP. The influence of radiotherapy on capsule formation and aesthetic outcome after immediate breast reconstruction using biodimensional anatomical expander implants. J Plast Reconstr Aesthet Surg. 2006;59(10):1043-1051. Doi: 10.1016/j.bjps.2006.01.051

29 Chun JK, Schulman MR. The infected breast prosthesis after mastectomy reconstruction: successful salvage of nine implants in eight consecutive patients. Plast Reconstr Surg. 2007;120(03): 581-589. Doi: 10.1097/01.prs.0000270296.61765.28

30 Yii NW, Khoo CT. Salvage of infected expander prostheses in breast reconstruction. Plast Reconstr Surg. 2003;111(03):1087-1092. Doi: 10.1097/01.PRS.0000046490.02212.BA

31 Bennett SP, Fitoussi AD, Berry MG, Couturaud B, Salmon RJ. Management of exposed, infected implant-based breast reconstruction and strategies for salvage. J Plast Reconstr Aesthet Surg. 2011;64(10):1270-1277. Doi: 10.1016/j.bjps.2011.05.009

32 Prince MD, Suber JS, Aya-Ay ML, Cone JD Jr, Greene JN, Smith DJ Jr, et al. Prosthesis salvage in breast reconstruction patients with periprosthetic infection and exposure. Plast Reconstr Surg. 2012; 129(01):42-48. Doi: 10.1097/PRS.0b013e3182361fbd

33 Brandstetter M, Schoeller T, Pülzl P, Schubert H, Wechselberger G. Capsular flap for coverage of an exposed implant after skinsparing mastectomy and immediate breast reconstruction. J Plast 
Reconstr Aesthet Surg. 2010;63(08):1388-1390. Doi: 10.1016/j. bjps.2009.11.054

34 Varga J, Mohos G, Varga Á, Erős G, Bende B, Németh IB, et al. A Possible technique for the complex reconstruction of exposed breast implant: applicability and microcirculation of the capsule flap. J Invest Surg. 2019;32(06):530-535. Doi: 10.1080/08941939.2018.1442532
35 Woerdeman LA, Hage JJ, Smeulders MJ, Rutgers EJ, van der Horst $\mathrm{CM}$. Skin-sparing mastectomy and immediate breast reconstruction by use of implants: an assessment of risk factors for complications and cancer control in 120 patients. Plast Reconstr Surg. 2006;118(02):321-330, discussion 331-332. Doi: 10.1097/01. prs.0000234049.91710.ba 